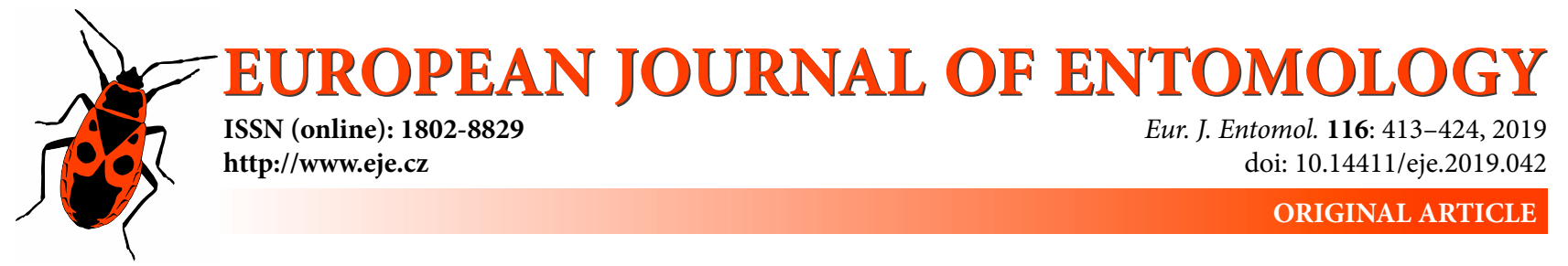

\title{
Current and predicted distribution of the rare and threatened beetle Bolbelasmus (Bolbelasmus) unicornis (Coleoptera: Geotrupidae) in Serbia
}

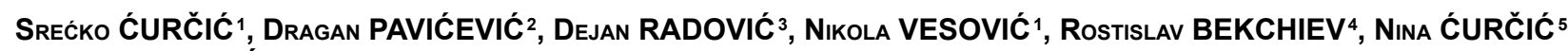 \\ and BoRISLAV GUÉORGUIEV ${ }^{4}$ \\ ${ }^{1}$ Institute of Zoology, University of Belgrade, Faculty of Biology, Belgrade, Serbia; e-mails: srecko@bio.bg.ac.rs, \\ nikola.vesovic@bio.bg.ac.rs \\ ${ }^{2}$ Krunska 15, Belgrade, Serbia; e-mail: dragan.pavicevic@hotmail.com \\ ${ }^{3}$ University of Belgrade, Faculty of Security Studies, Belgrade, Serbia; e-mail: dejanr2r@gmail.com \\ ${ }^{4}$ National Museum of Natural History, Bulgarian Academy of Sciences, Sofia, Bulgaria; e-mails: rbekchiev@gmail.com, \\ bobivg@yahoo.com \\ ${ }^{5}$ Geographical Institute “Jovan Cvijić”, Serbian Academy of Sciences and Arts, Belgrade, Serbia; e-mail: n.curcic@gi.sanu.ac.rs
}

Key words. Coleoptera, Geotrupidae, Bolbelasmus unicornis, soil-dwelling beetle, conservation, distribution, Serbia, new findings, GIS, modelling

Abstract. Bolbelasmus (Bolbelasmus) unicornis (Schrank, 1789) (Coleoptera: Geotrupidae) is a rare and threatened beetle distributed mostly in Central, Eastern and Southeast Europe. As a species of special conservation significance it is included in Annexes II and IV of the Habitat Directive of the European Union. Several new records of this species documented using light traps and soil sampling were recently reported in Serbia (the central part of the Balkan Peninsula). In this paper we present and discuss the current distribution of this species in the region studied based on GIS occurrence data. The distribution is mapped and values of environmental variables within this beetle's range are quantified using GIS technology. In addition, we predict its potential range in Serbia using a model based on the current distribution of this beetle, environmental variables and distribution of its food source.

\section{INTRODUCTION}

Bolbelasmus (Bolbelasmus) unicornis (Schrank, 1789) is very rare throughout its distribution range. Currently, it is known from Austria, Bosnia and Herzegovina, Bulgaria, Croatia, the Czech Republic, France (Alsace), Germany, Greece, Hungary, Italy, Moldova, Poland, Romania, Russia, Serbia, Slovakia, Slovenia, Switzerland, Ukraine and Turkey (Alonso-Zarazaga, 2013; Nikolajev et al., 2016). It is absent in Northern Europe, most of Western Europe, the Iberian Peninsula and the Apennines.

Bolbelasmus unicornis occurs in thermophilous steppe, forest steppe and Pannonian oak forest habitats (e.g., meadows, forest edges) in both lowland and hilly areas (Koren, 2017). It is seldom recorded because of its rarity and peculiar cryptic way of life. The latter seems to be the main reason why we know so little about this species. One of the priorities is to ascertain its way of life. This species is presumably associated with truffles (Tuber spp. and Choiromyces spp., Tuberaceae) and other hypogeous fungi (Glomus macrocarpum Tul. \& C. Tul., 1845, Endogonaceae) and uses them as food (Bratek et al., 1992; Nádai, 2006;
Miquel \& Vasko, 2014). This species burrows into the soil to reach hypogeous fungi (Ballerio et al., 2010). Adults are crepuscular and nocturnal and are attracted to light (Fabra, 2004; Ballerio et al., 2010). Juřena et al. (2008) report that adults fly low above the ground (cca. $1 / 2 \mathrm{~m}$ ), with the duration of each flight lasting 15-30 min and beginning about 40-45 min after sunset. Beetles fly before/after sunset and at night, mostly above meadows and along forest edges (Brelih et al., 2010). The adults are active mostly from late May to early July, but sometimes are observed in August and September (Juřena et al., 2008; Hillert et al., 2016).

Although this species is recorded in most of the countries in Southeast Europe, current knowledge about its regional distribution is relatively poor and differs significantly in extent from country to country (Koren, 2017). In the former Yugoslavia, there are only old records for Slovenia (five sites) (Brelih et al., 2010) and Bosnia and Herzegovina (two sites) (Mikšić, 1970; Lelo \& Kašić-Lelo, 2010), whereas for Croatia there is one old record and a single new record (Mikšić, 1970; Koren, 2017). In neighbouring Hungary it is not so rare (Nádai, 2006; Merkl et al., 2014), 
whereas in most of the other countries in Southeast Europe it is highly or extremely rare. There are, however, records of its occurring in Serbia in the past (Nedelkov, 1905; Mikšić, 1959; Gradojević, 1963; Guéorguiev \& Bunalski, 2004; Gavrilović \& Stojanović, 2008; Arnone \& Massa, 2010; Hillert et al., 2016). Surprisingly, the presence of this beetle in Serbia is not mentioned either in the Catalogue of Scarabaeoidea of Yugoslavia (Mikšić, 1970) or in the recent Catalogue of Palaearctic Coleoptera (Nikolajev et al., 2016).

It is a protected species in the European Union (EU). The EU lists it as a species of community importance in Annexes II [species requiring the designation of Special Areas of Conservation (SACs)] and IV of the Habitat Directive (species in need of strict protection) (European Commission, 1992), which ensure the preservation of its natural habitats and associated fauna and flora in Europe. Currently there are 36 SACs designated within the EU for the conservation of B. unicornis (EEA, 2016), but almost nothing is known about how the habitats need to be managed. Within the EU, the overall conservation status of $B$. unicornis is "unknown", since there are no data (for most countries) or very little information available (even for Hungary in the Pannonian region, where most of the records are reported). This beetle's conservation status is still not legally regulated in all countries, even in some belonging to the EU. The same applies for the non-EU member Serbia, where this species is not included in the Rulebook on Declaration and Protection of Strictly Protected and Protected Wild Species of Plants, Animals and Fungi (Anonymous, 2010, 2011). Some scientists assume that this species is declining throughout its entire distribution range and that there is a great need to conserve both the beetle and the habitats in which it lives (Szwałko, 2008). Since there are a small number of new records for most countries, each one is quite important and significantly increases our knowledge of the actual distribution of $B$. unicornis, which can in turn be used for the implementation of actions aimed at the conservation of this species and its habitats (Radović et al., 2005; Errouissi et al., 2009; Roslin et al., 2009; Horák et al., 2010; Numa et al., 2012; Dortel et al., 2013; Stojanović et al., 2017). Indeed, it is necessary to use existing information on this beetle's distribution and life history to improve conservation management. Distribution data are important in attempting to identify the possible extent of this beetle's occurrence, establish its current conservation status and define the geographical areas where it should be protected.

The aims of the present study were as follows: (i) report new records of this species in Serbia and summarize all known records for this country; (ii) provide a model of its current and predicted distribution in Serbia using geographic information system (GIS) technology and additional data on its ecology; and (iii) assess its conservation status in this country based on old records and the results of our own field studies.

\section{MATERIALS AND METHODS}

\section{Data from collections}

Several institutional collections [those of the National Museum of Natural History in Sofia (SOFM); the Natural History Museum in Belgrade; and the Institute of Zoology, University of Belgrade, Faculty of Biology] and private entomological collections [the collections of David Král, Prague, Czech Republic (CDK), Dragan Pavićević, Belgrade, Serbia (CDP) and Nastas Ilić, Belgrade, Serbia] were studied.

\section{Data from literature}

The data for Serbia in the following literature were summarized: Nedelkov (1905), Mikšić (1959), Gradojević (1963), Guéorguiev \& Bunalski (2004), Gavrilović \& Stojanović (2008), Arnone \& Massa (2010) and Hillert et al. (2016).

\section{Data from monitoring schemes}

We checked the results of monitoring schemes for both beetles and moths in Serbia conducted using light traps and soil sampling to confirm the presence of this beetle in this country during the last 20 years. Particularly in the period of 2013-2017 research was carried out in the northern, central and eastern parts of this country, where it was expected this species would occur.

The light trapping was part of the monitoring of moths and beetles in Serbia organized by the University of Novi Sad, Institute of Lowland Forestry and Environment and the University of Belgrade, Faculty of Biology. It was run from 2000 to 2017 (from February to November) over a large area of Serbia at approximately 350 locations at different altitudes and in different habitats (oak forests, grassland, forest edges) throughout the country (Fig. 1). There were a total of 294 UTM squares $(10 \mathrm{~km} \times 10 \mathrm{~km})$ where light traps were located within the confines of Serbia (almost $30 \%$ of the UTM squares in Serbia) (Fig. 1). High-pressure mercury discharge (VTF) light traps (consisting of a 400-W light bulb with a piece of white cotton canvas behind it) were used to collect specimens. Additional collections were made around street/outdoor lamps. Light traps were run each night from sunset for eight hours, from 19:00 to 3:00 h. The beetles were collected by hand or with an entomological net from around the light sources.

Soil sampling was done as part of the research on the endogean fauna of Serbia organized by the Institute for Nature Conservation of Serbia. It was done using special excavating equipment (e.g., pick axe) for digging into the soil up to a depth of $0.50 \mathrm{~m}$ over the last 30 years (from April to October) in a large area of this country at approximately 140 locations (other than the locations where light trapping was conducted) in Serbia proper and both provinces (Vojvodina and Kosovo and Metohija) at different altitudes and in a variety of habitats (Fig. 1). The 126 UTM squares $(10 \mathrm{~km} \times 10 \mathrm{~km})$ where soil sampling occurred in Serbia (13\% of the UTM squares in Serbia) are illustrated in Fig. 1. Soil sampling was done during the day, mainly beneath shrubs and in gardens.

The beetle material collected by both soil sampling and light trapping is deposited in the private collection of D. Pavićević (CDP) and in SOFM. Classification and nomenclature are those of Nikolajev et al. (2016). Locations and areas in Serbia mentioned in the current paper are shown in Fig. 2.

\section{GIS analysis and modelling}

The localities of B. unicornis that could be georeferenced were mapped using a GIS platform (program). We used vector data of hydrological features (rivers and lakes) to calculate distances between where the beetles were collected and the nearest hydrological entities using the Proximity toolset. We also mapped data on the distribution of the food sources of B. unicornis in Serbia (18 Tuber and Choiromyces taxa) (Ivančević, 2016). They are located in 80 UTM grid squares measuring $10 \mathrm{~km} \times 10 \mathrm{~km}$. We also used Corine Land Cover (CLC) seamless vector data (EEA, 2006) and raster data of: (i) a digital altitude model (http://www.webgis. 


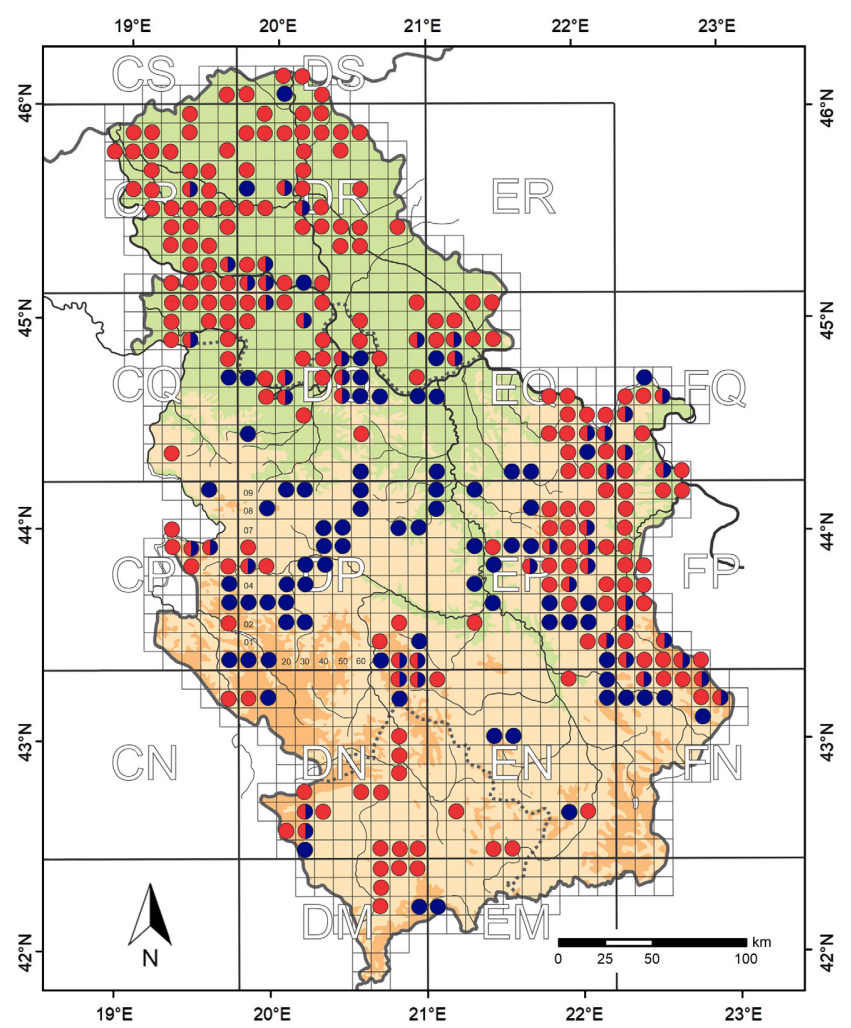

Fig. 1. Map of the localities in Serbia in UTM projection (grid zone 34T; basic square $10 \mathrm{~km} \times 10 \mathrm{~km}$ ) where light trapping (red circles and semi-circles) and soil sampling (blue circles and semi-circles) were conducted. The green areas are plains, the yellow areas hills and brown areas mountains.

com/srtm30.html); (ii) a digital model of average annual temperature [WorldClim - Global Climate Data (Hijmans et al., 2005)]; (iii) a digital model of average annual precipitation [WorldClim - Global Climate Data (Hijmans et al., 2005)]; and (iv) a georeferenced raster soil map of Serbia $(1: 2,000,000$, after Škorić \& Bogunović, 1977). The vector data and the database were integrated, analysed and processed using GIS software (ArcGIS 10).

The potential distribution of B. unicornis in Serbia was modelled using the distribution of the beetle and its food source (fungi) and environmental variables obtained from data on the beetle's distribution (altitude, average annual precipitation and average annual temperature). Numerical values for locations where beetles were collected were extracted using the ArcGIS Spatial Analyst tool. In the model, the potential distribution of the beetle is calculated using ArcGIS Spatial Analyst as the intersection where the variables of altitude, average annual precipitation and average annual temperature are within the defined values suitable for B. unicornis. For the potential distribution in Serbia, the presence of the potential food of the beetle is taken into account along with the three tested environmental variables using ArcGIS Spatial Analyst, assuming the extracted area is favourable for the occurrence of B. unicornis.

\section{RESULTS}

\section{Current knowledge of B. unicornis in Serbia based on data from collections and the literature}

After inspecting available institutional and private entomological collections, we found two specimens of $B$. unicornis collected in Serbia in the following collections: SOFM (one male from near the village of Babin Kal, Bela
Palanka) and CDK (one female from the village of Vrdnik, Mt. Fruška Gora) (Table 1). The two records of the beetle from the two above-mentioned collections are presented herein for the first time. These beetles were active at night, as were those previously reported for Serbia in the literature (Gavrilović \& Stojanović, 2008; http://www.biolib.cz/ en/image/id235093/; Stojanović, pers. comm.) (Fig. 3) as they were caught near light sources (light traps, street/outdoor lamps) late at night.

Analysis of the literature yielded a few additional records of B. unicornis from Serbia. In total, 18 specimens of the beetle are reported by previous authors from eight localities (Dimitrovgrad; Mt. Fruška Gora, village of Stražilovo; Ruma; Serbia; Đerdap National Park, 5 km WSW of Tekija; Krčedin; Đerdap National Park; and Jagoda, village of Deliblato, Deliblato Sands) (Table 1). Nedelkov (1905) reports this beetle in Dimitrovgrad (formerly Tsaribrod) (the locality was originally cited in Cyrillic). Until the end of 1919, the town of Tsaribrod and the surrounding area were within the boundaries of Bulgaria. Mikšić (1959) also reports it from Dimitrovgrad. He cited the town as "Caribrod" and erroneously indicates the record for Bulgaria. Guéorguiev \& Bunalski (2004) again restated Nedelkov's (ibid.) record. Data on the quantity and other collecting details were not given in the three above-mentioned references.

The locality near Tekija is erroneously indicated as within the boundaries of the Šumadija District (Hillert et al., 2016), but in fact is located in the Bor District. The same authors report one additional record in Serbia with uncertain location, so the precise position cannot be determined (Hillert et al., 2016). The record of Hillert et al. (2016) from the town of Ruma was first given by Arnone \& Massa (2010). Hillert et al. (2016) mention that Matcha collected one male specimen from Serbia, but a more precise locality was not specified. Literature records for the Đerdap National Park include two males and one female collected near Tekija (Hillert et al., 2016) and 11 females, the precise locations within the national park are unknown (https:/www.youtube.com/watch?v=ARWcwn9M2OM; https://www.youtube.com/watch?v=-jn7cHg84aY). The following three literature records are from the Vojvodina Province: one female was collected by Dejan Stojanović in the village of Stražilovo, Mt. Fruška Gora (Gavrilović \& Stojanović, 2008); one male was observed by Zoran Božović in Krčedin (http://www.biolib.cz/en/image/ id235093/; Božović, pers. comm.) and one specimen was collected by Zoran Gradojević in Jagoda, village of Deliblato, Deliblato Sands (Gradojević, 1963).

\section{Bolbelasmus unicornis - new records of its occurrence in Serbia and data collected using light traps and soil sampling}

New records of adults of $B$. unicornis from three sites in Serbia (Table 1) were obtained using light traps and soil sampling.

In spite of light trapping at approximately 350 locations in Serbia over a period of 18 years (2000-2017), this beetle was recorded only once (in 2003) (Table 1). Namely, one 


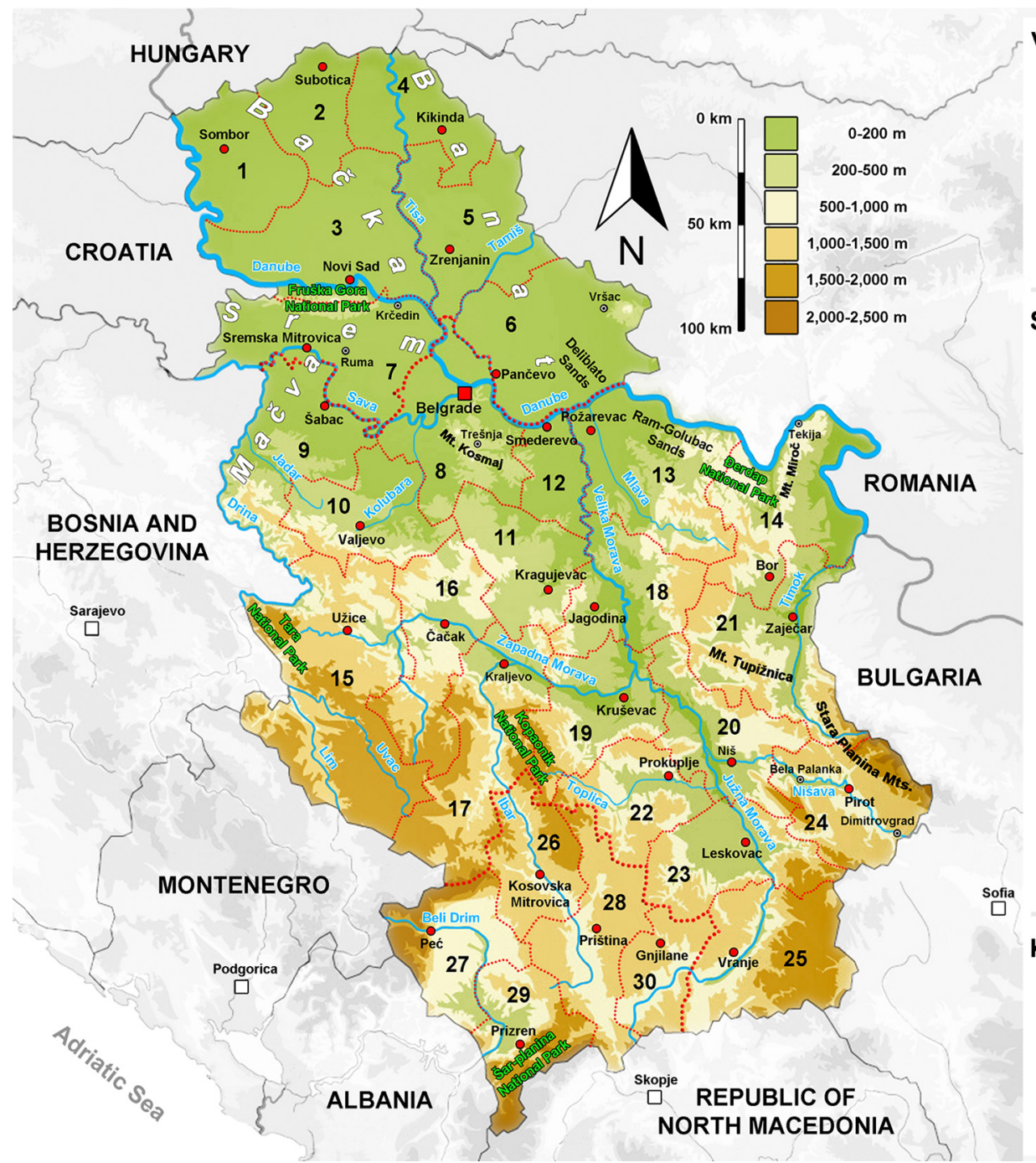

\section{Vojvodina Province \\ 1 - West Bačka \\ 2 - North Bačka \\ 3 - South Bačka \\ 4 - North Banat \\ 5 - Central Banat \\ 6 - South Banat \\ 7 - Srem}

\section{Serbia proper}

8 - City of Belgrade

9 - Mačva

10 - Kolubara

11 - Šumadija

12 - Podunavlje

13 - Braničevo

14 - Bor

15 - Zlatibor

16 - Moravica

17 - Raška

18 - Pomoravlje

19 - Rasina

20 - Nišava

21 - Zaječar

22 - Toplica

23 - Jablanica

24 - Pirot

25 - Pčinja

Kosovo and Metohija Province
26 - Kosovska Mitrovica
27 - Peć
28 - Kosovo
29 - Prizren
30 - Kosovo-Pomoravlje

Fig. 2. Map of Serbia showing provinces, regions, districts (numerical values) and their capitals (red dots), and the areas and locations mentioned in the text.

dead specimen was collected in daytime under an outdoor lamp at the Tresije Monastery, Mt. Kosmaj. Some areas in Serbia were systematically investigated for a long time using light trapping (e.g., environs of the cities of Sombor and Subotica on the Pannonian plain, Vojvodina Province and the Kopaonik and Tara National Parks, in Serbia proper), but no further findings were recorded (Mesaroš, pers. comm.; Vajgand, pers. comm.).

During the 30-year period of daily soil sampling at approximately 140 locations, beetles were dug up only twice, in 1986 and 2006 at two sites in Serbia, viz., at Trešnja in the hamlet of Grkovo, village of Mala Ivanča and in the village of Planinica, Mt. Tupižnica (Table 1). These beetles were found accidentally as there were no specific signs of their presence on the soil surface. It is important to point out that the specimen from Trešnja (hamlet of Grkovo, village of Mala Ivanča) was dug up beneath a hazel shrub together with Tuber fungi. The specimen from the village of Planinica was dug up in a garden.

\section{Period of activity of adults of $B$. unicornis in Serbia}

Adult beetles were recorded from May to July and most frequently in northern Serbia (Vojvodina Province), where they were collected in the Srem District from June to the middle of July (2005, 2013 and 2016). In eastern Serbia, it was recorded over the longest period, from May to the middle of July (2006 and 2014). In southeastern Serbia it was recorded at the beginning of July (2014), while in central Serbia (Šumadija region) it was recorded from the middle of May to the second half of June (1986 and 2003). The beetle was recorded four times in each of the two months of May and July, but somewhat less frequently in June (twice) (Table 1).

\section{Ecological preferences of $B$. unicornis in Serbia} Altitude preferences of $B$. unicornis

The presence of B. unicornis in Serbia is associated with low or medium-altitude habitats, from $104 \mathrm{~m}$ up to 741 $\mathrm{m}$ a.s.1., with an average altitude of $336 \mathrm{~m}$ a.s.l. (Table 2) (Fig. 4A). This species is mostly present on plains and in hilly areas, and to a somewhat lesser extent on the slopes 
Table 1. Records of the adult individuals of $B$. unicornis collected in Serbia.

\begin{tabular}{|c|c|c|c|c|c|}
\hline Site & $\begin{array}{l}\text { Additional site/collection } \\
\text { information for each record }\end{array}$ & $\begin{array}{l}\text { Time of } \\
\text { collecting }\end{array}$ & $\begin{array}{l}\text { Date of collecting and } \\
\text { collector/observer }\end{array}$ & $\begin{array}{l}\text { No. of specimens } \\
\text { and gender }\end{array}$ & Reference \\
\hline Dimitrovgrad & & & & & $\begin{array}{l}\text { Nedelkov (1905); Mikšić } \\
\text { (1959); Guéorguiev \& } \\
\text { Bunalski (2005) }\end{array}$ \\
\hline $\begin{array}{l}\text { Mt. Fruška Gora, } \\
\text { village of } \\
\text { Stražilovo }\end{array}$ & $\begin{array}{l}\text { Attracted by light trap in front of } \\
\text { bungalows by a stream near a } \\
\text { restaurant, surrounded by } \\
\text { deciduous forest and a meadow }\end{array}$ & At night & $\begin{array}{l}\text { 14.vii. } 2005, \text { Dejan } \\
\text { Stojanović }\end{array}$ & One female & $\begin{array}{l}\text { Gavrilović \& Stojanović } \\
\text { (2008); Gavrilović, pers. } \\
\text { comm.; Stojanović, pers. } \\
\text { comm. } \\
\end{array}$ \\
\hline Ruma & & & & One male & $\begin{array}{l}\text { Arnone \& Massa (2010); } \\
\text { Hillert et al. (2016) }\end{array}$ \\
\hline Serbia & & & Matcha & One male & Hillert et al. (2016) \\
\hline $\begin{array}{l}\text { Đerdap National } \\
\text { Park, } 5 \mathrm{~km} \text { WSW } \\
\quad \text { of Tekija }\end{array}$ & & & 27.-28.v.2014 & $\begin{array}{l}\text { Two males } \\
\text { and one female }\end{array}$ & Hillert et al. (2016) \\
\hline $\begin{array}{l}\text { Bela Palanka, } \\
\text { near the village } \\
\text { of Babin Kal }\end{array}$ & $\begin{array}{l}\text { A meadow and an orchard, } \\
\text { close to a Quercus/Carpinus } \\
\text { forest, attracted to a lamp }\end{array}$ & At night & $\begin{array}{l}\text { 03.vii.2014, Stoyan } \\
\text { Beshkov (SOFM) }\end{array}$ & One male & This study \\
\hline Krčedin & $\begin{array}{l}\text { Weeds/low shrubs, } \\
\text { attracted to a lamp }\end{array}$ & $21: 26: 41$ & $\begin{array}{l}\text { 01.vii.2013, Zoran } \\
\text { Božović }\end{array}$ & One male & $\begin{array}{c}\text { http://www.biolib.cz/en/ } \\
\text { image/id235093/; Božović, } \\
\text { pers. comm. }\end{array}$ \\
\hline $\begin{array}{l}\text { Đerdap National } \\
\text { Park }\end{array}$ & & & 13.vii.2014 & One female & $\begin{array}{l}\text { https://www.youtube.com/ } \\
\text { watch?v=ARWcwn9M2OM }\end{array}$ \\
\hline $\begin{array}{l}\text { Đerdap National } \\
\text { Park } \\
\end{array}$ & & & v.2014 & 10 females & $\begin{array}{c}\text { https://www.youtube.com/ } \\
\text { watch?v=-jn7cHg84aY }\end{array}$ \\
\hline $\begin{array}{c}\text { Deliblato Sands, } \\
\text { village of Deliblato, } \\
\text { Jagoda }\end{array}$ & $\begin{array}{l}\text { Festucetum vaginatae fumanetosum, } \\
\text { sand substrate rich in calcium } \\
\text { carbonate, with a deficit of humus }\end{array}$ & & Zoran Gradojević & & Gradojević (1963) \\
\hline $\begin{array}{c}\text { Village of Mala } \\
\text { Ivanča, hamlet } \\
\text { of Grkovo, Trešnja }\end{array}$ & $\begin{array}{l}\text { Dug up beneath a hazel shrub } \\
\text { together with Tuber fungi }\end{array}$ & $\begin{array}{l}\text { During } \\
\text { the day }\end{array}$ & $\begin{array}{l}\text { 14.v.1986, Dragan } \\
\text { Pavićević (CDP) }\end{array}$ & One female & This study \\
\hline $\begin{array}{c}\text { Mt. Kosmaj, } \\
\text { Tresije Monastery }\end{array}$ & $\begin{array}{c}\text { Dead specimen found } \\
\text { under a lamp near a restaurant }\end{array}$ & $\begin{array}{l}\text { During } \\
\text { the day }\end{array}$ & $\begin{array}{l}\text { 21.vi.2003, Dragan } \\
\text { Pavićević (CDP) }\end{array}$ & One female & This study \\
\hline $\begin{array}{c}\text { Mt. Tupižnica, } \\
\text { village of Planinica }\end{array}$ & Dug up in a garden & $\begin{array}{l}\text { During } \\
\text { the day }\end{array}$ & $\begin{array}{l}\text { 28.v.2006, Siniša } \\
\text { Ognjenović (CDP) }\end{array}$ & One female & This study \\
\hline $\begin{array}{l}\text { Mt. Fruška Gora, } \\
\text { village of Vrdnik }\end{array}$ & Attracted to light & At night & vi.2016 (CDK) & One female & This study \\
\hline
\end{tabular}

of mountains (Mts Fruška Gora, Tupižnica and Miroč, and those of the Stara Planina Mountains), with the records from low mountains less numerous (Mt. Kosmaj).

\section{Temperature preferences of $B$. unicornis}

The average annual temperature at the sites where this species occurred in Serbia ranges from $8.3^{\circ} \mathrm{C}$ to $11.5^{\circ} \mathrm{C}$, with a mean value of $10.2^{\circ} \mathrm{C}$ (Table 2). To judge from the data presented in Fig. 4B, it can be stated that B. unicornis prefers areas in the country in which the average annual temperature is moderate to high.

\section{Humidity preferences of $B$. unicornis}

Most of the records for Serbia are from sites near the Danube and its tributaries (Fig. 4A). The average annual precipitation at the sites studied in Serbia ranges from 608 $\mathrm{mm}$ to $745 \mathrm{~mm}$, with a mean value of $668 \mathrm{~mm}$ (Table 2). Thus, this beetle prefers areas in the country with moderate to low levels of humidity (Fig. 4C).

\section{Habitat and soil type preferences of $B$. unicornis}

Information about the habitats, types of areas and vegetation occurring at the sites inhabited by B. unicornis in Ser- bia were obtained using CLC data (Table 2) (Fig. 5). The following CLC codes applied to these sites were: 112, 211, 311, 321 and 324 (Table 3). At somewhat higher altitudes in the country, this species in most cases (six) was found in broad-leaved forests (311), predominantly oak forests, which are suitable for its food source (fungi). It is somewhat less present at higher altitudes, where it is mainly associated with shrub and/or herbaceous vegetation within forests and semi-natural areas [natural grasslands (321) and transitional woodland/shrub (324) (one case each)]. Interestingly, at low altitudes and on plains (at two lowaltitude sites in Srem District), this beetle was recorded under street lamps in urban areas (112). It is somewhat less associated at low altitudes with arable land in agricultural areas (211) (one case). At one site (Trešnja), hypogeous fungi (Tuber spp.) occurred.

According to the soil map of Serbia (Fig. 6), B. unicornis mostly prefers eutric brunisol, followed by chernozem on loess, limestone-dolomite black soil, lithosol and rendzina. Only once was it found on arenosol and eutric brunisol on sand, loessified soil and eutric brunisol and fluvial and eugley soil (Table 2). 


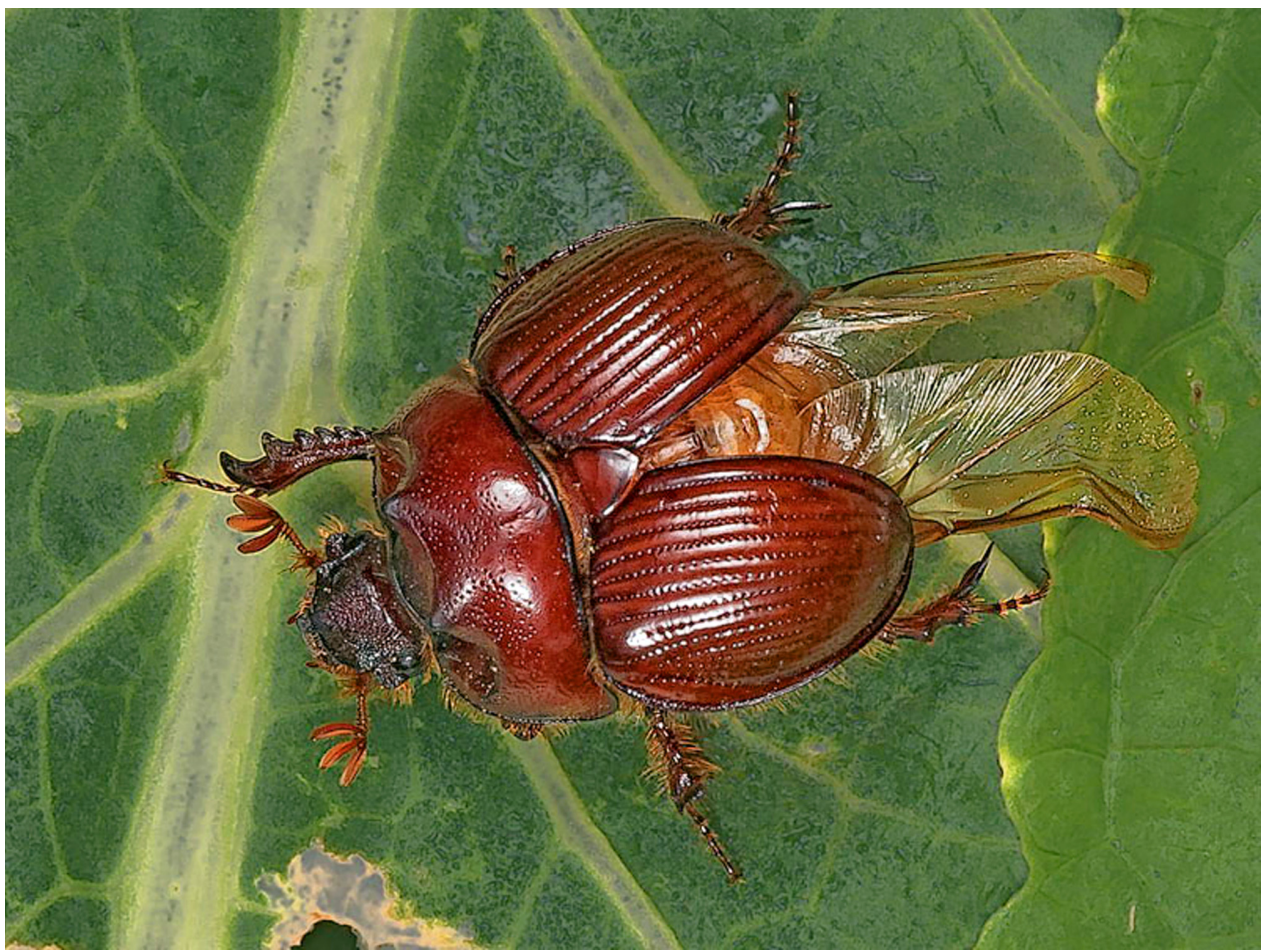

Fig. 3. Male of B. unicornis on a plant under a street lamp in Krčedin (northern Serbia) (photographed by Z. Božović).

Preference of $B$. unicornis for areas close to water bodies

The distance between the sites where this species occurred in Serbia and the nearest water bodies varied between $35 \mathrm{~m}$ and $2,426 \mathrm{~m}$, with a mean value of $972 \mathrm{~m}$ (Table 2) (Fig. 7).

\section{Predicted distribution of B. unicornis in Serbia}

Bolbelasmus unicornis is currently recorded in Serbia between latitudes $43.0085^{\circ}$ and $45.167133^{\circ} \mathrm{N}$ and between longitudes $19.798318^{\circ}$ and $22.772^{\circ} \mathrm{E}$ (Fig. 7).
Current distributions of both B. unicornis and this beetle's food (fungi) in Serbia are presented in Fig. 7. The map is helpful in predicting where we can expect new records of this beetle in the future, since its presence is closely associated with certain hypogeous fungi.

This together with the environmental variables associated with the data on this species distribution were used to produce a model of its potential distribution in Serbia, which is shown in Fig. 7. In northern Serbia (Vojvodina Province), it is likely it will be recorded in the future by the

Table 2. List of the locations where B. unicornis was recorded in Serbia. AES - arenosol and eutric brunisol on sand; $C L-c h e r n o z e m$ on loess; CLC - Corine Land Cover; EB - eutric brunisol; FE - fluvial and eugley soil; LEB - loessified soil and eutric brunisol; LLR limestone-dolomite black soil, lithosol and rendzina; RR - average annual precipitation; T - average annual temperature.

\begin{tabular}{|c|c|c|c|c|c|c|c|c|}
\hline Site & Latitude & Longitude & $\begin{array}{l}\text { Altitude } \\
\text { (m a.s.I.) }\end{array}$ & $\mathrm{T}\left({ }^{\circ} \mathrm{C}\right)$ & $\begin{array}{l}\mathrm{RR} \\
(\mathrm{mm})\end{array}$ & $\begin{array}{l}\mathrm{CLC} \\
\text { code }\end{array}$ & $\begin{array}{l}\text { Soil } \\
\text { type }\end{array}$ & $\begin{array}{c}\text { Distance from the } \\
\text { nearest water body }(\mathrm{m})\end{array}$ \\
\hline Dimitrovgrad & 43.008500 & 22.77200000 & 626 & 8.9 & 608 & 324 & $\mathrm{FE}$ & 834 \\
\hline $\begin{array}{l}\text { Mt. Fruška Gora, } \\
\text { village of Stražilovo }\end{array}$ & 45.167133 & 19.91672222 & 216 & 11.2 & 669 & 311 & EB & 245 \\
\hline Ruma & 45.004833 & 19.82000000 & 109 & 11.2 & 658 & 112 & $\mathrm{CL}$ & 881 \\
\hline $\begin{array}{l}\text { Đerdap National Park, } \\
5 \text { km WSW of Tekija }\end{array}$ & 44.643588 & 22.36049400 & 407 & 9.5 & 712 & 311 & LLR & 2,067 \\
\hline $\begin{array}{l}\text { Bela Palanka, near the } \\
\text { village of Babin Kal }\end{array}$ & 43.319157 & 22.38972100 & 741 & 8.3 & 641 & 321 & LLR & 544 \\
\hline Krčedin & 45.137333 & 20.12600000 & 113 & 11.5 & 636 & 112 & $\mathrm{CL}$ & 1,662 \\
\hline $\begin{array}{l}\text { Deliblato Sands, village } \\
\text { of Deliblato, Jagoda }\end{array}$ & 44.835242 & 21.05116600 & 104 & 11.3 & 651 & 211 & AES & 2,426 \\
\hline $\begin{array}{l}\text { Village of Mala Ivanča, } \\
\text { hamlet of Grkovo, Trešnja }\end{array}$ & 44.607376 & 20.57124600 & 260 & 10.5 & 705 & 311 & EB & 318 \\
\hline $\begin{array}{c}\text { Mt. Kosmaj, } \\
\text { Tresije Monastery }\end{array}$ & 44.465593 & 20.56399200 & 542 & 9.2 & 745 & 311 & LEB & 1,251 \\
\hline $\begin{array}{l}\text { Mt. Tupižnica, village } \\
\text { of Planinica }\end{array}$ & 43.837847 & 22.11952600 & 350 & 9.8 & 650 & 311 & EB & 425 \\
\hline $\begin{array}{l}\text { Mt. Fruška Gora, } \\
\text { village of Vrdnik }\end{array}$ & 45.124595 & 19.79831800 & 229 & 10.9 & 675 & 311 & EB & 35 \\
\hline
\end{tabular}



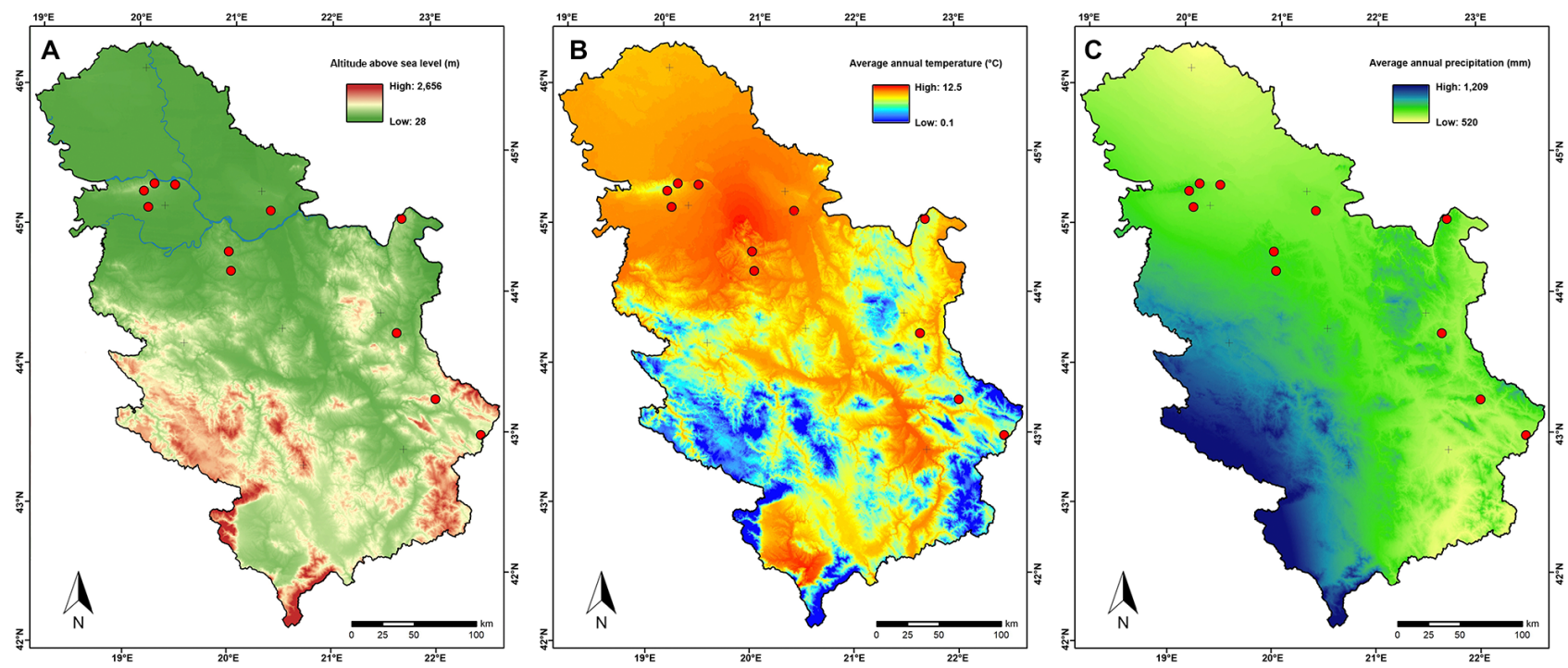

Fig. 4. Distribution of $B$. unicornis in Serbia on digital models based on altitude (A), average annual temperature (B) and average annual precipitation $(C)$. The red dots indicate the locations where this beetle is recorded. Projected coordinate system: Europe Albers Equal Area Conic.

Danube and its tributaries in the Srem (Mt. Fruška Gora and its surroundings) and Bačka Districts, and on the Deliblato Sands and by the Vršac Canal (Vršačke Planine Mts and its surroundings) in the Banat District. It is possible it occurs in a small part of western Serbia by the Sava River and its tributaries (Kolubara River) in the Mačva and Kol-

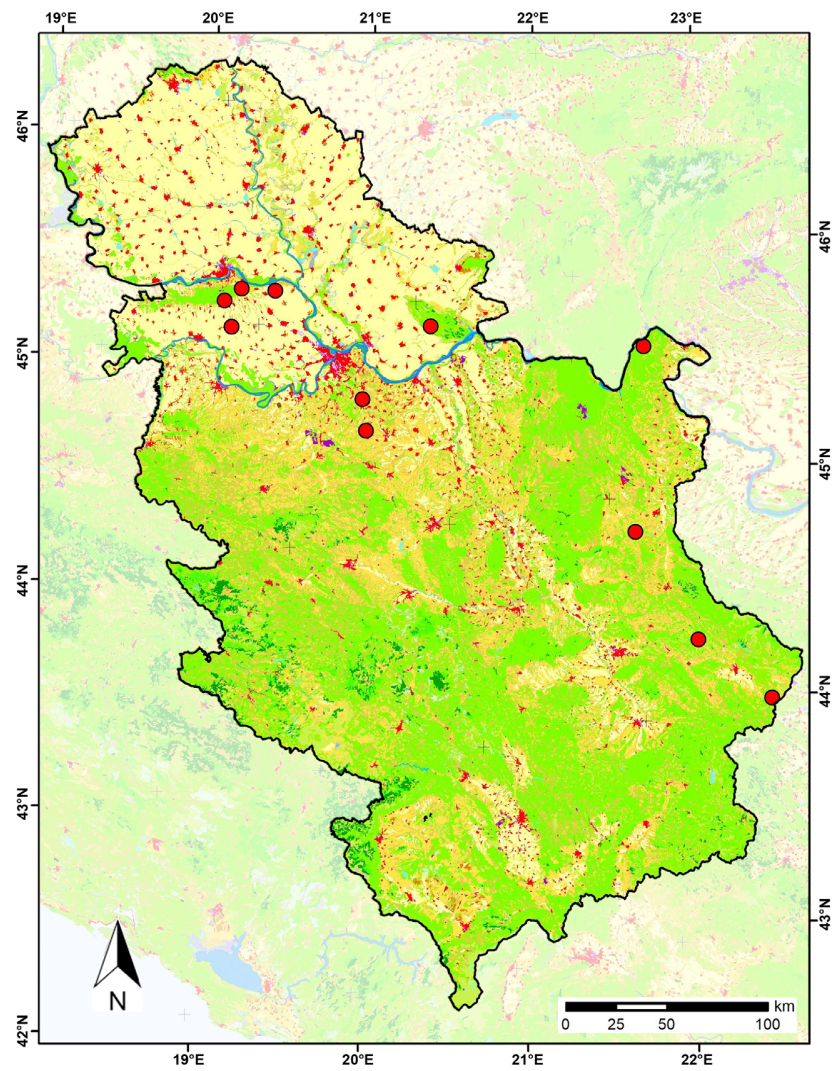

Fig. 5. Corine Land Cover 2006 data and distribution of B. unicornis in Serbia. The blue surfaces are major rivers and lakes, while the red dots are the locations where this beetle is recorded. Projected coordinate system: Europe Albers Equal Area Conic. ubara Districts. In Serbia proper, a significantly larger area is predicted to be suitable for $B$. unicornis. It includes the valleys of the rivers Velika Morava and its smaller tributaries, Zapadna Morava (part of), Danube (along the border with Romania and in the City of Belgrade and Podunavlje Districts), Mlava, Timok, Nišava (part of), Toplica, Ibar (part of), and Južna Morava (part of). The northwestern, northeastern central, eastern, southeastern, and southern parts of the country seem suitable for B. unicornis, while the northern, western, southwestern, and southeasternmost parts are unfavourable for this beetle (Fig. 7).

\section{DISCUSSION}

\section{Current distribution of B. unicornis in Serbia}

Our analyses indicate that the distribution of B. unicornis in Serbia is closely linked with the distribution of its food (fungi), environmental parameters considered (altitude, average annual temperature and precipitation), soil type and proximity to water bodies (Koča, 1906; Nitzu, 2001; Byk et al., 2016). The finding of B. unicornis in Trešnja (hamlet of Grkovo, village of Mala Ivanča), beneath a hazel shrub together with Tuber fungi, supports the assumption that the beetle is likely to feed on these fungi. In a few cases, the locations of this beetle and its food (fungi) either overlap or are close to each other. In most cases, however, the distributions do not overlap, indicating that other environmental factors may also influence this beetle's distribution.

The distribution of this beetle in Serbia is not particularly localized. Its presence in eastern and southeastern Serbia is confirmed in the vicinity of Bela Palanka (the second record in the valley of the Nišava River) and Zaječar (the first record in the valley of the Timok River). Apart from the Pannonian steppe, the beetle prefers river valleys in Serbia proper (eastern and southeastern Serbia) with similar environmental conditions and/or is found mostly at somewhat higher altitudes (on low mountains or mountain slopes) (Šumadija region). The greatest number of records are 


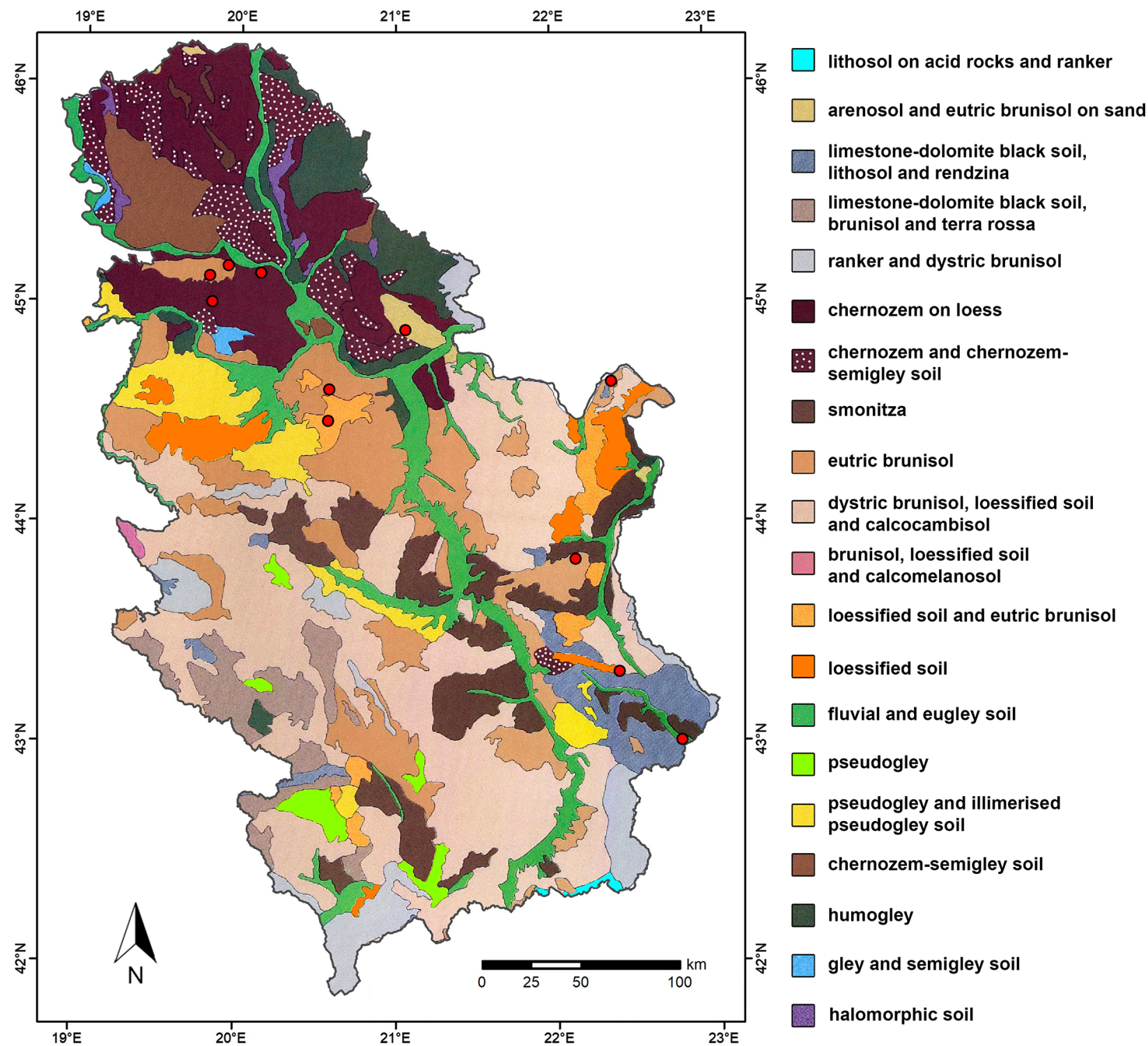

Fig. 6. Current distribution of B. unicornis in Serbia superimposed on a soil map (after Škorić \& Bogunović, 1977). The red dots are the locations where this beetle is recorded. Projected coordinate system: MGI / 3-degree Gauss zone 7.

from the Srem District (four), confirming the connection with forest-steppe habitats in the vicinity of the Danube. Interestingly, it is important to point out that the presence of this beetle on the Deliblato Sands (Banat District) indicates that it might also inhabit sandy soil (arenosol and eutric brunisol on sand), so future attention should be paid to other similar areas in Serbia (e.g., the Ram-Golubac Sands and other sands in the Podunavlje region). The records of this beetle in areas close the Serbian border with surrounding countries [Gorna Malina in the vicinity of Vidin (unpubl. data) and the Lozenska Planina Mts in western Bulgaria (Guéorguiev \& Bunalski, 2004); in Szekszárd, on Csukma Hill and on Mt. Villányi in southern Hungary (Nádai, 2006); and in Vinkovci and the nearby village of Gradište in eastern Croatia (Koča, 1906; Koren, 2017)] indicate that it might also be present on the Serbian side, near the border (by the Danube and its tributaries in the Bačka and Srem Districts and in the valleys of the Nišava and the Timok Rivers in southeastern Serbia).

Table 3. Corine Land Cover (CLC) codes for the locations where B. unicornis is recorded in Serbia.

\begin{tabular}{cccc}
\hline CLC code & Label 1 & Label 2 & Label 3 \\
\hline 112 & Artificial surfaces & Urban area & Discontinuous urban area \\
211 & Agricultural areas & Arable land & Non-irrigated arable land \\
311 & Forests and semi-natural areas & Forests & Broad-leaved forest \\
321 & Forests and semi-natural areas & Associations of shrub and/or herbaceous vegetation & Natural grasslands \\
324 & Forests and semi-natural areas & Associations of shrub and/or herbaceous vegetation & Transitional woodland/shrub \\
\hline
\end{tabular}




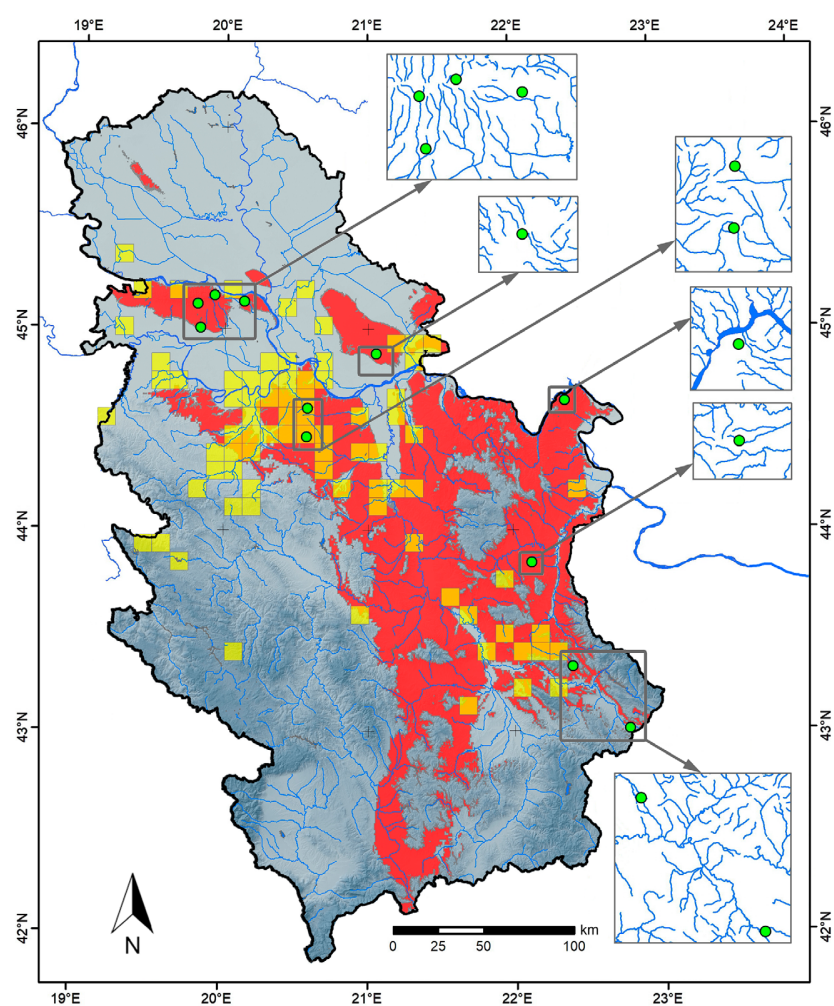

Fig. 7. Current distribution of $B$. unicornis in Serbia and the predicted distribution of this beetle in this country on a digital altitude model. The green dots are the locations where this beetle is recorded, the yellow squares locations where fungi, its food source, were recorded. The blue surfaces are major rivers and lakes, the different shades of grey the different altitudes, while the red area is that predicted as suitable for this beetle based on a combination of the three environmental variables measured (altitude, average annual temperature and average annual precipitation) and the distribution of its food source. A detailed hydrological network around the locations of the records of this beetle is shown in the insets (map magnified $2 \times$ ). The data on distribution of the fungi are those cited in Ivančević (2016). Projected coordinate system: MGI / 3-degree Gauss zone 7.

\section{Effectiveness of different sampling methods}

The number of adult individuals collected using light trapping over a long period of time in a large area of Serbia was only three. Attraction to light was also documented in the case of one specimen observed in Krčedin by Zoran Božović (Božović, pers. comm.). Our efforts using soil sampling and collecting above vegetation resulted in gathering only two individuals. This indicates that this beetle is rare in this country and that light trapping is slightly more effective than soil sampling, but the former method of collecting needs to be combined with soil sampling, collecting above vegetation at dusk, truffle locating by dogs and pigs, etc. It seems that light trapping is still the most effective method of collecting for monitoring purposes (Král, 2006; Ballerio et al., 2010).

Existing collecting methods need to be combined with novel ones in order to determine this beetle's cryptic way of life and whether it is rare or not in a certain area. Therefore, use of the results of GIS analyses of data on the locations of records of this beetle and the environmental variables documented has to be taken into account in the future. This will lead to improved rates of detection. It is of a special interest to have accurate data on the locations (GPS coordinates, Corine Land Cover type) and environmental variables for the sites where $B$. unicornis occurs (altitude, temperature, humidity, soil type, distance from the nearest water body) on a European scale. After obtaining such data, it will be possible to conduct a broader GIS analysis, which will give us the most precise information on the ecology of this species.

\section{Abundance and activity of $\boldsymbol{B}$. unicornis in Serbia}

The number of individuals collected in Serbia is very low (one specimen per site). Reports in the literature in most instances are of only one specimen per site in Serbia, except for the case of those collected in May of 2014 in the Đerdap National Park (https://www.youtube.com/ watch? $v=-j n 7 \mathrm{cHg} 84 \mathrm{aY}$ ) and on 27-28 May 2014 in the vicinity of Tekija, Đerdap National Park, of 10 and three specimens, respectively (Hillert et al., 2016).

Adult beetles were recorded in Serbia from May to July, which is in accordance with the data on seasonal activity in the literature (Juřena et al., 2008; Hillert et al., 2016). Our records were for May, June and July, while Serbian records in the literature are for only May and July (Gavrilović \& Stojanović, 2008; Hillert et al., 2016; http:// www.biolib.cz/en/image/id235093/; https://www.youtube. com/watch?v=ARWcwn9M2OM; https://www.youtube. com/watch? $\mathrm{v}=-\mathrm{jn} 7 \mathrm{cHg} 84 \mathrm{aY})$. The specimens collected by light trapping were clearly active at night as they were gathered until midnight. Such is the case of a specimen reported by Gavrilović \& Stojanović (2008) (Gavrilović, pers. comm.; Stojanović, pers. comm.) and a specimen observed by Zoran Božović (http://www.biolib.cz/en/image/ id235093/; Božović, pers. comm.). One dead specimen collected during the day was presumably attracted to light as it was found under an outdoor lamp. The remaining two specimens collected during daytime were dug up from soil. The time of capture of specimens in Serbia reported by most previous authors (Nedelkov, 1905; Mikšić, 1959; Gradojević, 1963; Guéorguiev \& Bunalski, 2004; Arnone \& Massa, 2010; Hillert et al., 2016) was not recorded.

\section{Number of records of $B$. unicornis in Serbia and surrounding countries}

If we compare the number of records for Serbia (14) with those for surrounding countries, this beetle is more frequently documented only in Hungary (76 records) (Nádai, 2006), while a smaller number of records are reported for Bulgaria (10) (Guéorguiev \& Bunalski, 2004; unpubl. data), Romania (four) (Nitzu, 2001; Popescu \& Davideanu, 2009; Hillert et al., 2016) and Bosnia and Herzegovina and Croatia (two each) (Lelo \& Kašić-Lelo, 2010; Koren, 2017). There are currently no records for the Republic of North Macedonia and Albania. The number of the records for Serbia indicates that it is rare in this country and in most other countries it is extremely rare (Brelih et al., 2010; Koren, 2017), except in Hungary, where it is found relatively frequently (Nádai, 2006; Merkl et al., 2014). Chemical contamination of the environment and 
ploughing negatively affect the food source of this beetle (Szwałko, 2008), which is becoming increasingly rare in Poland. The above factors are also likely to influence the occurrence of this beetle throughout its distribution area (Szwałko, 2008).

\section{Ecological preference of $B$. unicornis}

Altitude preferences of $B$. unicornis

This beetle occurred at a somewhat higher average altitude in Serbia (336 m a.s.1.) than at other sites in Europe and Asia Minor (Paill, 2008; Hillert et al., 2016; Koren, 2017; GBIF.org, 2018), i.e., localities in Austria, Slovakia, Hungary, France, Romania, the Czech Republic, Turkey, Ukraine and Croatia (236 $\mathrm{m}$ a.s.1.).

\section{Preference of $B$. unicornis for the proximity of water in Serbia and surrounding countries}

This species occurred in areas in Serbia relatively close to water bodies (rivers). The sites studied in Serbia are relatively close to the Danube and its tributaries. The distribution of this beetle in Serbia overlaps with the river system of the Danube. The distribution of this beetle in surrounding countries (Koča, 1906; Nitzu, 2001; Guéorguiev \& Bunalski, 2004; Nádai, 2006; Byk et al., 2016; Koren, 2017) also indicates that it might be associated with the nearness of flowing and stagnant water in areas where its food (fungi) occurs. Thus, the vicinity of water bodies (canals, rivers, lakes) should also be taken into account as an additional environmental factor in predicting the areas in Serbia where this beetle is likely to occur. In Bulgaria, it is found mostly on the Danube Plain and to a lesser extent close to the Black Sea or smaller rivers in its drainage basin (Guéorguiev \& Bunalski, 2004). A similar pattern is evident for the Romanian locations (close to rivers, lakes, or the Black Sea) (Nitzu, 2001; Popescu \& Davideanu, 2009; Hillert et al., 2016) and Hungarian records (most locations close to the Danube and Lake Balaton) (Nádai, 2006). The two Croatian records are from the vicinity of the Bosut River (Koča, 1906; Koren, 2017), a tributary of the Sava River. The present centre of the beetle's range is the Pannonian region, though one could suggest that the real range of B. unicornis overlaps more or less with the overall river system of the Danube. This is not the case for the Italian records, which are from the vicinity of the Tagliamento River (Benasso, 1971; Zandigiacomo, 2005), which is part of the Adriatic river system.

\section{Preference of $B$. unicornis for particular habitats and soil types in Serbia}

The beetles recorded in Serbia were collected in broadleaved forests (six locations); discontinuous urban areas (two locations); and non-irrigated arable land in agricultural areas, natural grasslands and transitional woodland/ shrub (one location in each). It mostly prefers forest habitats in Serbia, but can be found in areas strongly affected by human activity (agricultural areas and artificial surfaces). It favours low-altitude undisturbed/disturbed habitats in Serbia. This is in accordance with data from other countries (Horion, 1958; Vrezec et al., 2011) and indicates that this beetle is thermophilous and inhabits low-altitude areas (steppes and steppe forests), especially thin oak forests. It is an indicator species for natural grasslands (Vrezec et al., 2011) and is not recorded in chemically polluted soils (Szwałko, 2008).

As for this beetle's preference for particular types of soil, it is important to point out B. unicornis close association with its food source (Tuber spp. and Choiromyces spp.), which is mostly associated with fluvial and eugley soils, eutric brunisol, dystric brunisols, loessified and brown soils on limestone and dolomite, and chernozem on loess (Ivančević, 2016). This beetle prefers chernozem on loess and eutric brunisol in the Srem District; arenosol and eutric brunisol on sand in the Banat District; and mostly eutric brunisol and limestone-dolomite black soil, lithosol and rendzina in Serbia proper (Nejgebauer et al., 1961). The close association of this beetle with fluvial soils accords with its affinity for the proximity of water bodies.

\section{Predicted range of $B$. unicornis in Serbia}

The distribution of this beetle in Serbia covers a relatively wide range of geographic latitudes and longitudes. The extent of this range could be even greater according to our model's prediction of its distribution in this country, which indicates it might occur in the northwestern (a small area south of the Sava River), central (a huge area), eastern (almost entire area), southeastern (a small area) and southern parts (a narrow area). This beetle has not been recorded in northwestern or southern Serbia, where it is also expected to occur. Currently, it is not possible to map the distribution of its food source (fungi) over a large area, since the data on its distribution is incomplete, especially on the Balkan Peninsula.

\section{Candidates for SACs in Serbia}

As a future member state of the EU, Serbia will be obliged by law to fulfil all the requirements of the EU's environmental criteria and will have to designate one or more SACs for B. unicornis based on the available data. This will prevent the degradation of localities of interest and conserve the beetle, its habitats and the rest of the fauna in these habitats. For example, as a measure of the effort put into the conservation of this beetle, a total of 36 SACs are designated in the EU (EEA, 2016), the greatest number of which are located in Hungary and Bulgaria, where the greatest number of records are reported.

The following areas in Serbia are potential candidates for SACs: Fruška Gora National Park and its surroundings (with four records) and Đerdap National Park (with three records). This will reinforce the current level of conservation of this species, since these two areas are already legally protected. Special attention should be paid to research on this beetle in areas in the vicinity of the two national parks (especially in broad-leaved forests and urban areas), where this species can be expected to occur. After obtaining more complete knowledge about the distribution of $B$. unicornis in this country, it will be possible to assess its population status, develop appropriate conservation measures and improve monitoring. 


\section{Measures for conservation of $B$. unicornis in Serbia}

The very few new records of this beetle in Serbia indicate that further field surveys are needed in order to ascertain its complete distribution in this and neighbouring countries and assess its conservation status in the region. We propose that further research be carried out in areas predicted by our model to be suitable for this species in Serbia. It is very important that this species is immediately added to the official national lists of protected species in Serbia. In addition, it is desirable that this species should be considered and adopted for inclusion in Red Lists and Red Data Books at the regional level.

ACKNOWLEDGEMENTS. This study was financially supported by the Serbian Ministry of Education, Science, and Technological Development (Grants Nos. ON173038, III-46002 and III-47007) We are grateful to J. Glamočlija (Institute for Biological Research "Siniša Stanković", Belgrade, Serbia), P. Zandigiacomo (Department of Agricultural, Food, Environmental and Animal Sciences, University of Udine, Udine, Italy) and W. Brunnbauer (Natural History Museum, Vienna, Austria), who provided us with some of the literature used herein. Z. Božović (Belgrade, Serbia) gave us his data on one record of collecting B. unicornis in Serbia and allowed us to include his photograph of the beetle in the manuscript. Apart from that, we thank S. Beshkov (National Museum of Natural History, Sofia, Bulgaria) for the record from near Bela Palanka. Finally, for additional unpublished records of this beetle from Mt. Fruška Gora, we are grateful to D. Král (Faculty of Science, Charles University, Prague, Czech Republic), D. Stojanović (Institute of Lowland Forestry and Environment, Novi Sad, Serbia) and B. Gavrilović (Geographical Institute "Jovan Cvijić", Serbian Academy of Sciences and Arts, Belgrade, Serbia). We thank two anonymous reviewers for their constructive comments, which helped us improve the manuscript.

\section{REFERENCES}

Alonso-Zarazaga M.A. 2013: Fauna Europaea: Geotrupidae. Fauna Europaea Version 2017.06. URL: https://fauna-eu.org (last accessed 14 Nov. 2018).

ANONYMOUS 2010: Rulebook on declaration and protection of strictly protected and protected wild species of plants, animals and fungi. - Sl. Glasn. Rep. Srb. 5: 46-98 [in Serbian].

ANONYMOUS 2011: Rulebook on amendment of the Rulebook on declaration and protection of strictly protected and protected wild species of plants, animals and fungi. - Sl. Glasn. Rep. Srb. 47: 134-158 [in Serbian].

Arnone M. \& Massa B. 2010: A new species of Bolbelasmus Boucomont, 1911 from Sicily (Italy). — Natur. Sicil. 34: 401414.

Ballerio A., Rey A., Uliana M., Rastelli M., Rastelli S., Romano M. \& Colacurcio L. 2010: Coleotteri Scarabeoidei d'Italia. Collana Piccole Faune, Brescia, 13 pp. + DVD.

Benasso G. 1971: Una specie nuova per il Friuli: Bolbelasmus unicornis (Schrank) (Coleoptera Geotrupidae). - Atti Mus. Civ. Stor. Nat. Trieste 27: 167-172.

Bratek Z., Papp L., Merkl O. \& Takacs V. 1992: Insects associated with hypogeous fungi. - Mikol. Kozlem. 31: 55-66 [in Hungarian].

Brelih S., Kajzer A. \& Pirnat A. 2010: Material for the beetle fauna (Coleoptera) of Slovenia. 4th contribution: Polyphaga: Scarabaeoidea (= Lamellicornia). - Scopolia 70: 13-86 [in Slovenian].
Byk A., Mokrzycki T., Rosa-Gruszecka A., Tylkowski S. \& ZAMOJSKI M. 2016: Bolboceratidae and Ochodaeidae - activity, ecological requirements and methods of observation. - Stud. Mater. Cent. Eduk. Przyr.-Leś. R. 18: 124-141 [in Polish].

Dortel E., Thuiller W., Lobo J.M., Bohbot H., Lumaret J.P. \& JAY-Robert P. 2013: Potential effects of climate change on the distribution of Scarabaeidae dung beetles in Western Europe. - J. Insect Conserv. 17: 1059-1070.

EEA 2006: Corine Land Cover 2006 Seamless Vector Data. URL: http://www.eea.europa.eu/data-and-maps/data/clc-2006-vector-data-version (last accessed 14 Nov. 2018).

EEA 2016: Bolbelasmus unicornis Schrank, 1789. URL: http:// eunis.eea.europa.eu/species/196422 (last accessed 14 Nov. 2018).

Errouissi F., Labidi I. \& Nouira S. 2009: Seasonal occurrence and local coexistence within scarabaeid dung beetle guilds (Coleoptera: Scarabaeoidea) in Tunisian pasture. - Eur. J. Entomol. 106: 85-94.

European Commission 1992: Council Directive 92/43/EEC of 21 May 1992 on the Conservation of Natural Habitats and of Wild Fauna and Flora. URL: http://eur-lex.europa.eu/legal-content/ EN/TXT/?uri=CELEX:31992L0043 (last accessed 14 Nov. 2018).

FABRA P.R. 2004: Biologie de Bolbelasmus gallicus (Mulsant, 1842) dans le département du Gard (Languedoc, sud de la France). - Elytron 17: 37-46.

Gavrilović B. \& Stojanović D. 2008: The Scarabaeidae (Coleoptera, Insecta) of Mount Fruška Gora. In Ćurčić S.B. (ed.): The Diversity of Coleoptera of the Fruška Gora National Park. Part One. Fruška Gora National Park \& Directorate of Forests, Ministry of Agriculture, Forestry, and Water Management of the Republic of Serbia, Novi Sad, pp. 89-105.

GBIF.org 2018: GBIF Occurrence Download. URL: https://doi. org/10.15468/39omei (last accessed 14 Nov. 2018).

Gradojević Z.M. 1963: Settlements of Arthropoda of the Grass Communities of the Deliblato Sands and Their Succession. $\mathrm{PhD}$ thesis, University of Belgrade, Belgrade, 239 pp. [in Serbian].

GuÉorguiev B. \& Bunalski M. 2004: Critical review of the families Glaresidae, Lucanidae, Trogidae, Bolboceratidae, Geotrupidae, Hybosoridae and Ochodaeidae in Bulgaria (Coleoptera: Scarabaeoidea). - Acta Zool. Bulg. 56: 253-276.

Hijmans R.J., Cameron S., Parra J., Jones P., Jarvis A. \& RichARDSON K. 2005: WorldClim - Global Climate Data. Free Climate Data for Ecological Modeling and GIS. URL: http:// www.worldclim.org/ (last accessed 14 Nov. 2018).

Hillert O., Arnone M., Král D. \& Massa B. 2016: The genus Bolbelasmus in the western and southern regions of the Mediterranean Basin (Coleoptera: Geotrupidae: Bolboceratinae). Acta Entomol. Mus. Nat. Pragae 56: 211-254.

Horák J., VÁvrová E. \& Сновот K. 2010: Habitat preferences influencing populations, distribution and conservation of the endangered saproxylic beetle Cucujus cinnaberinus (Coleoptera: Cucujidae) at the landscape level. - Eur. J. Entomol. 107: $81-88$.

Horion A. 1958: Faunistik der Mitteleuropäischen Käfer. Band VI: Lamellicornia (Scarabaeidae - Lucanidae). August Feyel, Überlingen am Bodensee, 343 pp.

IvANČEvić B.N. 2016: Spatial Distribution and Ecological Variations of the Habitats of Hypogean Macromycetes (Mycota) in Serbia. PhD thesis, University of Belgrade, Belgrade, 331 pp. [in Serbian].

JuŘEnA D., TÝr V. \& BEZDĚK A. 2008: Contribution to the faunistic research on Scarabaeoidea (Coleoptera) in the Czech Republic and Slovakia. - Klapalekiana 44: 17-176 [in Czech]. 
KoČA G. 1906: A list of beetles of the surroundings of Vinkovci (Enumeratio coleoptorum circa Vinkovce inventorum). Glasn. Hrv. Nar. Društ. 17: 119-212 [in Croatian].

Koren T. 2017: The status and occurrence of Bolbelasmus unicornis Schrank, 1789 (Coleoptera: Geotrupidae) in Croatia. Acta Zool. Bulg. 69: 139-142.

KRÁL D. 2006: Unicorn Scarab - Bolbelasmus unicornis (Schrank, 1789). Monitoring Methodology of Species of European Importance. Agency for Nature Conservation and Landscape Protection of the Czech Republic, Prague, 6 pp. [in Czech].

Lelo S. \& Kašıć-Lelo M. 2010: The Biodiversity of Scarabs (Insecta: Coleoptera, Scarabaeoidea) of Bosnia and Herzegovi$n a$. Association for Inventarization and Protection of Animals, Ilijaš, 70 pp. [in Bosnian].

Merkl O., KöDöBöcz V., TAmás D. \& Tiвor D. 2014: Faunistic data to the beetles from the south-eastern Great Hungarian Plain (Coleoptera). — Crisicum 8: 99-152 [in Hungarian].

MIKŠIĆ R. 1959: Dritter Nachtrag zur "Fauna Insectorum Balcanica - Scarabaeidae". — God. Biol. Inst. Univ. Sarajevu 12: 47-136.

MIKšıć R. 1970: Katalog der Lamellicornia Jugoslawiens (Insecta-Coleoptera). Institute of Forestry, Sarajevo, $71 \mathrm{pp}$.

Miquel M.E. \& VASKo N.V. 2014: A study of the association of Odontaeus armiger with the European rabbit. - J. Entomol. Zool. Stud. 1: 157-167.

NÁDAI L. 2006: Hungarian localities of the species of Bolboceratinae (Coleoptera, Scarabaeoidea: Geotrupidae). — Folia Hist.-Nat. Mus. Matraen. 30: 205-210 [in Hungarian].

Nedelkov N. 1905: A contribution to the Bulgarian insect fauna. —Period. Spis. Bulg. Knizh. Druzh. Sofia 66: 404-439 [in Bulgarian].

Nejgebauer V., Ćirić M. \& Živković M. 1961: Commentary to the Soil Map of Yugoslavia 1:1,000,000. Yugoslav Society for Soil Investigation, Belgrade, 107 pp. [in Serbian].

Nikolajev G.V., KRÁl D. \& BezděK A. 2016: Family Geotrupidae Mulsant, 1842. In Löbl I. \& Löbl D. (eds): Catalogue of Palaearctic Coleoptera. Vol. 3, Scarabaeoidea, Scirtoidea, Dascilloidea, Buprestoidea, Byrrhoidea. Revised and Updated Ed. Brill, Leiden, Boston, pp. 33-52.
NitzU E. 2001: Edaphic and subterranean Coleoptera from the Dobrogean karstic areas (Romania). A zoogeographic approach. - Mitt. Hamb. Zool. Mus. Inst. 98: 131-169.

Numa C., Lobo J.M. \& Verdú J.R. 2012: Scaling local abundance determinants in Mediterranean dung beetles. - Insect Conserv. Diver. 5: 106-117.

Paill W. 2008: Wiederfund von Bolbelasmus unicornis (Schrank, 1789) in der Wiener Donauauen (Coleoptera: Scarabaeoidea: Geotrupidae). - Beitr. Entomofaun. 8: 165-171.

Popescu I.E. \& Davideanu A. 2009: Conservation status of protected or rare invertebrates from the border area Romania - Republic of Moldova. - AES Bioflux 1: 43-53.

Radović D., Stevanović V., Marković D., Jovanović S., Džukić G. \& RADOVIĆ I. 2005: Implementation of GIS technologies in assessment and protection of natural values of National Park Tara. — Arch. Biol. Sci. Belgrade 57: 193-204.

Roslin T., Avomaa T., Leonard M., Luoto M. \& Ovaskainen O. 2009: Some like it hot: microclimatic variation affects the abundance and movements of a critically endangered dung beetle. - Insect Conserv. Diver. 2: 232-241.

Stojanović D., Vajgand D., Radović D., Ćurčić N. \& ĆurČić S. 2017: Expansion of the range of the introduced moth Acontia candefacta in southeastern Europe. - Bull. Insectol. 70: 111-120.

SzwaŁko P. 2008: Bolbelasmus unicornis (Schrank, 1789). Polish Red Book of Animals - Invertebrates. URL: http://www.iop. krakow.pl/pckz/opisc7fc.html?id=180\&je=pl (last accessed 14 Nov. 2018).

ŠKorić A. \& Bogunović M. 1977: The Soil Map of Yugoslavia 1:2,000,000. Institute of Pedology, Faculty of Agriculture, Zagreb [in Croatian].

Vrezec A., Pirnat A., Kapla A., Polak S., Vernik M., Brelih S. \& Drovenik B. 2011: Status and knowledge about beetles (Coleoptera) of European conservation importance in Slovenia with proposal of Slovenian nomenclature. - Acta Entomol. Slov. 19: 81-138 [in Slovenian].

Zandigiacomo P. 2005: Nuovo rinvenimento di Bolbelasmus unicornis (Schrank) (Coleoptera, Geotrupidae) in Friuli Venezia Giulia. - Boll. Soc. Nat. "Silvia Zenari" Pordenone 29: 75-79.

Received November 14, 2018; revised and accepted October 16, 2019 Published online November 21, 2019 